\title{
Bounded Reliability and the Termination of International Joint Ventures \\ - Insights from the Mid-Med Bank, 1975-1979
}

\author{
Qing Lu ${ }^{1}$ \\ Hull University Business School \\ University of Hull, UK
}

This is an Accepted Manuscript of an article published by Taylor \& Francis in Business History on 19 Jan 2019, available online:

https://www.tandfonline.com/doi/full/10.1080/00076791.2018.1552679.

1 Contact Address: Hull University Business School, University of Hull, Cottingham Road, Hull HU6 7RX, UK. Email: Q.Lu@Hull.ac.uk. 


\title{
Bounded Reliability and the Termination of International Joint Ventures \\ - Insights from the Mid-Med Bank, 1975-1979
}

\begin{abstract}
In the late Twentieth Century, the international joint venture (IJV) became an increasingly important yet unstable organisational form of international business. Based on insights provided by the Mid-Med Bank of Malta during the period 1975-1979, this paper argues that the unanticipated termination of IJVs has endogeneity due to the bounded reliability of their partners' decision makers, developed from the formative stage and influenced by inter/intra organisational relationships along the evolution of the IJVs. The findings thus contribute to our understanding of the nature of bounded reliability, contractual governance and the bargaining process.
\end{abstract}

Key words: bounded reliability, international joint venture termination, contractual governance, obsolescing bargain, Barclays

\section{Introduction}

At the core of international business is the multinational company (MNC), whose origin can be traced back to the colonial era (Wilkins, 1970). An important and popular organisational form of the MNC is the international joint venture (IJV), which is an equity-based partnership between organisations from different countries (Inkpen, 2009). For example, in China, one of the largest recipients of foreign direct investment (FDI) in the world, 51\% of FDI in value was invested in IJVs during the period between 1979 and 1997 (Bai, Tao \& Wu, 2004). The popularity of the IJV has been attributed to its advantages in helping the MNC guard against technical, economic and political risks in host countries through the support of local partners. In addition, nationalist governments in developing countries, particularly since the era of decolonisation, have tended to prefer IJVs to wholly- owned foreign subsidiaries because the former are 
more likely to meet their political and economic requirements, for instance in being able to offer not only foreign technology and capital but also guaranteeing the transfer of management skills to local companies (Berlew, 1984; Killing, 1982).

The IJV, however, has often been described as an inherently unstable organisational form and prone to failure (Inkpen, 2009). The termination rate of modern IJVs ranges from 30 to 70 per cent (Inkpen \& Beamish, 1997), where termination is defined as the end of a partnership even if the firm's physical existence survives. Ninety per cent of terminations are unintended, in terms of the stated purpose at the formation of the IJV (Makino, Chan, Isobe \& Beamish, 2007). As a result, their high termination rate has stimulated researchers to explore why unintended termination occurs and how to improve their contractual governance.

The extant research about IJVs’ contractual governance (Beamish \& Banks, 1987) has drawn upon and further extended the internalisation theory of MNCs (Buckley \& Casson, 1976; Rugman, 1979) to include the framework provided by the transaction cost paradigm developed by Williamson (1975). As the decisions to form and terminate IJVs are made by specific individuals, many scholars have emphasised the importance of understanding individuals' behaviour in IJV termination research (Wathne \& Heide, 2000; Williamson, 1975, 1985). Following Williamson's framework and the assumption of opportunistic human behaviour in economic transactions, opportunism has become the central concept in the study of IJV failure (Hennart, 1988; Oxley, 1997; 
Parkhe, 1993). Every IJV contract, it is claimed, has the object of coping with the threat of opportunism (Luo, 2005).

Based on the good-faith sources of commitment failure informed by the research of business historians on the micro-level details of managerial practice, bounded reliability, a new fundamental assumption about human behaviour, has been developed to further extend the assumption of opportunism (Kano \& Verbeke, 2015; Rugman \& Verbeke, 2005; Verbeke \& Greidanus, 2009; Verbeke \& Kano, 2010, 2013). This concept holds that an individual's reliability in fulfilling their commitment can be bound not only by malevolent elements, such as opportunism and malfeasance, but also by benevolent elements, such as benevolent preference reversal due to ex post reprioritisation or ex ante over-commitment, and identity-based discordance due to individuals' stated or assumed promises conflicting with their personal identity or with their original practices. Different from bounded rationality, which is more closely related to 'scarcity of mind' due to imperfect information and imperfect information processing capacity, bounded reliability is more closely related to scarcity of effort in fulfilling an open-ended promise (Verbeke \& Kano, 2013; Foss \& Weber, 2016; Lumineau \& Verbeke, 2016). Bounded reliability is then also different from the concept of trustworthiness in economic transactions. The former is an assumption of endogenous human behaviour that can lead to individual commitment failure regardless of a partner's desire at the outset of a contract to fulfill commitments. It can be involuntary as well as voluntary and can occur at any time during the period of a contract from the outset to the end. In 
contrast, the latter is an attribute applied to an individual exogenously by others based on the perceived willingness of that individual to fulfill commitments set in a contract, which in turn is related to the levels of social capital accumulated by the individual and the information resources and monitoring and enforcement capabilities at the disposal of those applying the attribute. Furthermore, as the termination of the IJV also means the obsolescence of the original bargain, we would like to ask three main research questions:

1. How does bounded reliability help explain the unintended termination of IJVs?

2. What are the emergent bounded reliability elements in this specific context?

3. How does bounded reliability help us better understand the bargaining process?

The complexity and longitudinal nature of IJV terminations, and their growing importance to international business, call out for more historical case studies. This paper thus for the first time, addresses the above questions based on insights gained from a study of the Mid-Med Bank, an IJV between the Maltese Labour Party (MLP) government and Barclays Bank during the period 1975-1979. The stated intention in the Agreement was for a long-lasting IJV but this partnership lasted for only five years. This paper also suggests ways in which the contractual governance of IJVs might be improved to mitigate the threat of bounded reliability. It therefore addresses wider concerns in the history and theory of international business about contractual performance and commitment failure in cross-border transactions. 


\section{Literature review, materials and methodology}

Only a few business historical works have explored the reasons for IJV termination, in sharp contrast to the larger number that focus on the role of the IJV (Álvaro-Moya, 2015; Colli, 2014; Jones, 2003; Lee \& Jin, 2009; McGovern \& McLean, 2017; Richardson, 1984) and its operation and management (Michie, 1978; Pugach, 1982). Moreover, due to the longitudinal nature of business history research (Langley, 2009; Menard, 2008; Wilkins, 2009), the limited range of works on this topic, such as Pilkington (1996), have all regarded the formation, post-formation and termination of the IJV as a seamless whole. Their findings, which tend to assume a post hoc ergo propter hoc view, have suggested that partners' reliability at the formative stage was limited, although the issue of bounded reliability has neither been clearly identified nor explored.

Although the extant research about bounded reliability provides some explanation of commitment failure in international business and entrepreneurship, it is still a relatively new, multifaceted concept requiring further conceptual development and refinement based on different contextualisation (Kano \& Verbeke, 2015; Verbeke \& Kano, 2010, 2013). Furthermore, the extant research about bounded reliability is mainly based on the context of one organisation. Little consideration of individual bounded reliability in the context of inter-organisational relationships exists except for the study by Marcos \& Prior (2017) which explores the role of individual bounded reliability in supplier- 
buyer relationship decline.

Furthermore, a popular theory explaining the deterioration of the host government MNC bargaining relationship is the obsolescing bargain theory (OBT) (Vernon, 1971; Haggard, 1989; Gould \& Winters, 2007; Dunning \& Lundan, 2008; Álvaro-Moya, 2015; Abdelrehim \& Toms, 2017). Based on the extractive and manufacturing industry, it attributes the deterioration to the MNCs' obsolescing bargaining power when their investment was sunk and the host government acquired the management capability. In our research, the MNC, i.e. Barclays Bank, is in the financial industry, which had already been operating for many years in the host country of Malta. The majority of its staff had become localised, i.e. the Maltese government had the capacity to absorb its operation (Barclays Group Archives [BGA], 1959, 1963, 1974a). Given the British government's non-involvement attitude (Moreton, 1972; National Archives [NA], 1975a, 1977a), following the extant OBT, Barclays would possess little bargaining power in the formation of the IJV bank. Our research, however, showed that there was a significant difference in Barclays's bargaining power between that at the formative stage and the end. What, then, was the origin of Barclays' bargaining power at the formative stage? How does bounded reliability help explain the obsolescence of the bargain?

The main data sources upon which this research is based are the Barclays Group Archives and the UK Government National Archives. The rich archival data covers the entire life of the partnership from inception to termination, and supplies details of the 
decision makers' behaviour within the partnership, including their communication and interaction, and inter/intra organisational relationship among/within relevant organisations to the partnership. A small body of secondary literature provides useful context about the relevant organisations and inter/intra relationship among/within them. Although Ackrill and Hannah (2001) refer to the operation of Barclays in Malta in their company history, they do not discuss Barclays’ activities in Malta in any depth, far less those of the Mid-Med Bank.

To address the three research questions, we used an abductive approach to analyse the data, which involved an iterative comparison between relevant IJV termination literature, bounded reliability literature, OBT literature and our data (Danermark, Ekström, Jakobsen, \& Karlsson, 1997), following which we detect the following emergent themes. First, as the termination or partners' commitment failure must be legitimised, they must have prepared for this failure in their contract. Then how will this contribute to the bounded reliability of their decision makers? How will this contribute to the obsolescence of the bargain? Second, Parkhe (1991) has argued that the study of IJVs involves intra-organisational decision-making and interorganisational relationships within/among relevant organisations to the partnership, including the two contractual partners and others involved directly or indirectly in the formation of the IJV, in our case notably the British government and the Malta Union of Bank Employees (MUBE) (See Table 1). Then how will the partners' intraorganisational relationship contribute to their decision makers' bounded reliability? 
How will the inter-organisational relationship contribute to the bounded reliability of the partners' decision makers?

In the following sections, first, we introduce the context of the formation of the MidMed Bank and then explore the factors that contributed to the bounded reliability of partners' decision makers, causing them to consider the possibility of commitment failure at the formative stage. Next, we explore how decision makers' bounded reliability, influenced by inter/intra organisational relationships, led to their commitment failure along the evolution of the IJV partnership. Finally, this paper summarises the findings of the research and offers some suggestions about how to improve the contractual governance of IJVs.

\section{The Context of the Formation of the Mid-Med Bank}

The formation of the Mid-Med Bank took place during the post-colonial era. When the former colonial countries achieved independence, their national governments tended to adopt state control or nationalisation policy, as a result of domestic development and rising expectations, combined with a lack of confidence in foreign companies which were seen as a symbol of Western colonialism (Nye, 1974; Kobrin, 1984). As a result, MNCs in these countries had to be involved in continuous bargains with local governments about restructuring their local business, protecting their local assets, or at worst, receiving reasonable compensation. 
Malta achieved its independence from the United Kingdom (UK) in 1964. As Malta's strategic value had decreased considerably to the Western Alliance since the end of the Second World War, the UK started to gradually withdraw its military forces. Accordingly, the Maltese government signed two Agreements about the British military base in Malta: the Anglo-Maltese Defence Agreement and the Financial Assistance Agreement, according to which the British government agreed to pay the Maltese government a sum not exceeding M£50 million (M£1 = Stg£1.35) over a 10-year period (1964-1974) for using the military base (NA, 1975b).

The Maltese economy had significantly relied on the British military base. For many years nearly 25 per cent of Malta's labour force was employed in serving the British naval and military installations. The rent charged by the Maltese government and the expenditure of the British forces in Malta amounted to at least M£30m annually, representing almost 25 per cent of the country’s GNP (NA, 1975a). Malta therefore suffered the economic consequences of the rundowns (NA, 1967).

\section{The MLP Government: its decision maker Mintoff and state control policy}

In 1971, the MLP won the general election and came to power, with Mr. Dom Mintoff becoming Prime Minister. Although according to the Constitution's prescription, the Opposition Party, namely the Nationalist Party (NP), Parliament and other members of the Cabinet should all have been involved in the government decision-making process, 
in reality the process was dominated by Mintoff (Moreton, 1972). First, Mintoff succeeded in amending the Constitution in 1974 in order to restrict the influence of the Church on Maltese politics and to restrict the power of Parliament by granting the government the right to have the final say in all matters (NA, 1975c). Second, the government moved increasingly towards withholding information from Parliament (Shaw, 1975a). Although Mintoff continued to face pressure from the NP and its supporters (NA, 1975d, 1975a), the NP's response lacked cohesion due to its internal disorder and strife over the leadership succession (Eldred, 1976). Third, Mintoff gave his Ministers and Civil Servants very little leeway, as regards making their own decisions (Mizzi, 1995). Fourth, Mintoff used his power to stifle dissent through bullying, intimidation and political patronage. As a result, since Mintoff came to power in 1971, no MLP member of Parliament had ever voted against his government. When Paul Carachi announced in July 1974 that he would from that moment be independent of any political party, he was rapidly forced to withdraw his announcement (Shaw, 1975b). Fifth, Mintoff adopted a policy of increasing state control through the large scale nationalisation of private and foreign business. This process was entirely controlled by Mintoff for use against his political opponents (Mizzi, 1995; NA, 1975d). For example, when the broadcasting service was nationalised, it became an arm of the government and only broadcast pro-government propaganda. Even the journalist responsible for reporting parliamentary matters was a member of the Executive Committee of the MLP (Shaw, 1975b). 
Mintoff's centralisation of power was supported by the public confidence and trust in him due to his outstanding political performance in negotiating with foreign governments for the benefit of Malta (Barclays Head Office in Malta [BHOM], 1975). One example of this was the 1972 Military Facilities Agreement which replaced the previous two Agreements signed in 1964. As a result, the British government agreed to increase the annual rent for using Malta's facilities by a factor of approximately three and reschedule their military run-down by extending the deadline to 1979 (NA, 1976a). Another example was that in 1974, the Maltese government had further success in negotiating with the British government concerning Constitutional amendments, as a result of which, Malta changed from a Monarchy to a Republic and the executive authority in Malta was returned to its own President (NA, 1978d).

Furthermore, Mintoff's dominant position was supported by the largest trade union in Malta, the General Workers' Union (GWU) (Moreton, 1972), with an estimated membership of 25, 683, at the beginning of 1974 (NA, 1975e). As the GWU and the MLP were the two main organisations of the labour movement in Malta, they had common members and support (Mizzi, 1995). The GWU thus supported Mintoff and his MLP. Due to Mintoff's centralisation of power, the GWU's decision-making was actually significantly influenced by Mintoff (NA, 1978a).

The reason for Mintoff centralising power was to facilitate the achievement of his objective: to turn Malta into a neutral state whose economy would be self-sufficient and 
need not rely on rent from foreign users of its military facilities (NA, 1975a). Due to his dominant position in the government, his objective became the government's objective, which was reflected in the Development Plan for Malta 1973-1980 published in 1972 (NA, 1975b). The main policy proposed by the Plan was for state control and investment in order to generate sufficient foreign exchange income to tackle problems caused by the run-down of the British military base (Alexander, 1975). In addition, Mintoff sought to achieve this aim through diversified relationships with other countries, including western countries, the Soviet Union, China and Libya, so that no single country could significantly affect Malta’s economy (NA, 1975a, b). Malta also took an active role in the Non-Aligned Movement (Haydon, 1975).

Mintoff's target in the Development Plan was, however, over-ambitious, given the limited capital sources held by the government, which seriously constrained its investment potential (NA, 1975f). The MLP government thus emphasised the importance of foreign capital and developed its policy towards forming IJVs with foreign MNCs (Malta Chamber of Commerce, 1974).

\section{The British Government Policy towards Malta}

Regarding Malta, maintaining a good relationship with the Maltese government was the British government's policy. First, during the 1970s, the Western countries were no longer able or willing to use their power to protect foreign investments (Kobrin, 1984; Kennedy, 1992). According to the 1972 Military Facilities Agreement, the British 
government preferred to encourage political tranquility in order to facilitate a smooth and orderly run-down rather than support the remaining few British firms, as the total value of assets was approximately £3-4 million (NA, 1975a, 1977a; Winchester, 1977a). Second, given Mintoff’s ‘diversified relationships’ strategy, it was important to both the UK and NATO to avoid Malta siding with the Warsaw Pact countries or certain Arab states (NA, 1976b). Third, there were mutual benefits for Malta and the UK in the British government helping Mintoff to achieve his objectives. For Malta, the benefit was prosperity and stability, whereas for the UK, the 1972 Agreement would prove workable and would run its course. Otherwise, if it became apparent that Mintoff was not making progress towards his economic goals, he might turn to complete state control of the economy and a closer political relationship with communist countries (Moreton, 1972).

The above British government policy was mainly decided by its Prime Minister. According to the Constitution, the British government had a Cabinet system and the decision-making process was consultative: the Prime Minister was the key decisionmaker but all Ministers would be consulted in making the final decision (Parliamentary Archives, 1975). In reality, since the Second World War, the decision-making power had been gradually centralised by the Prime Minister, who functioned as a 'chief executive figure’ (Foley, 2000: 244). When Harold Wilson became Prime Minister 1974-1976, he also dominated the decision-making process within the government. First, he controlled information about the government by depriving Cabinets of vital 
information. Second, in order to secure compliance, he adopted the unfettered force of preferment or dismissal. As the choice of Cabinet members and their department was decided by Prime Minister, less and less did the Cabinets actually exercise their decision-making power (Coates, 1977).

\section{Trade Unions in Malta}

Since 1948, the Maltese government had continuously involved trade unions in their formulation of national policy as Malta was one of the highest unionised countries in Europe, with more than one in two workers being trade union members (Baldacchino, 2009). Next to the GWU, the Confederation of Malta Trade Union (CMTU) was the largest union. It was in reality a confederation of unions, one of which was the Malta Union of Bank Employees (MUBE). It was not affiliated to any political party. The trade unions adopted a voting process that made the key decision-makers difficult to identify, while also producing a single voice for collective bargaining (Undy \& Martin, 1984). Following the legacy and traditions of British colonial rule, trade unions were actively involved in bargaining about wages and working conditions rather than the basic conditions of employment and the national minimum wage which were established by law (Rizzo, 2009).

\section{Barclays Bank and its Engagement Policy}

Barclays Bank had started operations in Malta in 1925. By the end of 1974, the Bank controlled about 60 per cent of the Maltese banking business; the only other foreign 
bank was the Lombard Bank (Malta) Ltd, a wholly owned subsidiary of National Westminster Bank Plc (BGA, 1974c). Given his policy of state control, Mintoff wanted to restructure the Maltese banking sector and place the entire banking system under direct government control (Shaw, 1975c). Out of concern for the impact such a policy might have on foreign investment, however, Mintoff did not want to nationalise the two foreign banks (BGA, 1975a). Regarding the Lombard Bank (Malta) Ltd, the government achieved a 25 per cent share but then opted to increase this to 60 per cent (Shaw, 1975c). With regard to Barclays, the government proposed a partnership in building a new IJV bank.

When Barclays’ representatives from Head Office in London visited Malta, Mintoff made the following promises to them regarding the new bank. First, the government 'wanted Barclays' continued presence in Malta, on a friendly basis'. He wished to 'regard any arrangements with Barclays on a commercial rather than on a political basis'. Second, 'the government did not wish in any way to interfere in Barclays' management' of the new bank. It wanted 'control of general policy but not of management', as it accepted that 'Barclays was the banker and not the government'. Third, the government 'mainly desired to get for Malta a proper share of the profits' from Barclays’ operation' (BGA, 1973b). Mintoff's promise reflected that based on his perception of Barclays' role in helping foreign investment, he did assume that Barclays had relative bargaining power. His promise became the base of their bargaining. 
Facing the turbulence and uncertainty of the world post-colonial economic and political environment, there was a trend of centralisation in Barclays Bank's strategic decisionmaking. More decisions were made at the centre in London rather than at local head offices. The central decision-making process was consultative among the Board members with Anthony Favill Tuke who took office as the Chairman in 1972 being the key decision-maker (Ackrill \& Hannah, 2001). The attitude of the Board members, especially Tuke, toward the independence of former colonial countries was always cooperative. They adopted a general principle of engagement if there were mutual benefits for Barclays and the local government (BGA, 1973a, 1974b, 1975b). The objectives of Barclays' engagement policy were to develop Barclays into 'a fully international bank providing a satisfactory return on capital employed, concurrent with the maintenance of high standards of service to the community'. The then figure of 'a satisfactory return' was 20 per cent per annum before tax (BGA, 1971).

Facing Mintoff's proposal, Barclays had to accommodate it due to its vulnerable position in Malta. Besides the unpleasant international and domestic political environment for MNCs, Barclays also had a significant proportion of its business in Malta. In 1975, Barclays’ assets and liabilities in Malta reached £83M, with 700 staff and 40 branches (BGA, 1975c), which was around 2\% of Barclays' assets and liabilities, overseas staff and branches, respectively (Ackrill and Hannah, 2001). This may not seem hugely significant, but Barclays’ business was widely dispersed across more than 70 countries and over $60 \%$ of its accounts were held in the UK and six Southern African countries (Ackrill and Hannah, 2001). This left 40\% spread across more than 60 
countries and made $2 \%$ of the total quite a significant proportion. Barclays could either make good use of them to make a profit or sell them at a reasonable price, both options being at the mercy of the MLP government (BGA, 1978a, 1978b).

Furthermore, the local operation was mainly run by Maltese managers and staff as Barclays had started staff localisation in Malta in 1959 (BGA, 1959, 1963). In October 1974, at least three out of the five Barclays Bank Malta Board members were Maltese, including both the Chairman, Louise Edward Galea who was also 'the first local director to be appointed from locally engaged staff in any territory where Barclays operates' (BGA, 1974a), and the Deputy Chairman, Leslie James Castillo. The local branch managers retiring in 1974 and 1975 were also Maltese (BGA, 1974d, 1975d). In addition, the fact that the majority staff joined the MUBE indicated that most of the staff were local (BGA, 1977a). The high level of staff localisation indicated that Malta possessed enough domestic human capital if the government wanted to absorb Barclays’ local operations.

In addition, given the Maltese government's policy of state control, Barclays' Board saw business opportunities in the government-intensive investment. Following their engagement policy, they agreed to build a partnership with the Maltese government although they were warned by the local Head Office of the political risk that might incur extra costs for Barclays’ commitment to the partnership (BHOM, 1975). 
Facing Mintoff's firm requirement, Barclays had to agree to convert its local institutions into those of the new bank with 40 per cent shares and no right of veto as its representatives thought 'it was quite useless to put up any other proposal and indeed it could be provocative' (BGA, 1973b, 1975e). Mintoff accepted Barclays’s request to remove the word 'Barclays' from the name of the new bank. Eventually the new bank's name was the Mid-Med Bank. The Agreement was signed on 31 ${ }^{\text {st }}$ March 1975 and the new bank was scheduled to start operations from $1^{\text {st }}$ October 1975. The two partners' intention for the partnership to continue for not less than ten years was clearly stated in the Agreement.

\section{The Development of Bounded Reliability at the Formative Stage}

In spite of the two partners' stated intention for a long-lasting partnership, their credibility was restricted by their decision makers' bounded reliability in the above context.

Mintoff's bounded reliability started when he made the aforementioned three promises to Barclays as his promises contrasted with the then dominant policy, with which he identified, i.e. state control and investment and minimising the role played by MNCs in the local economy. Mintoff's perception of the dominant policy thus would affect his promise fulfillment by inducing him to regress to it. This discordance indicated Mintoff's internal psychological conflict, which was, however, consistent with his 
personal character: 'full of energy and brimming with new ideas' and change by adopting 'almost invariably unorthodox' means and methods, which thus made him quite unpredictable: 'his aim is very often quite the opposite, or at any rate, different from what he appears to be seeking' (Mizzi, 1995, pp. 5-6). Furthermore, Mintoff's dominant position, both within the MLP government and in the partnership, indulged his development of bounded reliability.

As a result, the terms of the Agreement clearly reflected Mintoff's preparation for his regression to the state control policy, i.e. commitment failure. First, one important aspect of Mintoff's state control policy was to narrow the income gap between lowincome and high-income earners. Although Mintoff promised Barclays that the government would consider any arrangement with the latter on a commercial rather than on a political basis, he wanted Barclays to accept the responsibility for compensating for the relevant salary reduction involved through a terminal benefit payment, which followed his strategy of nationalising private entities, such as Rediffusion, Cable and Wireless (Mizzi, 1995). The normal localisation practice experienced by Barclays in other parts of the world was that the staff of foreign banks would maintain continuity of employment, when the local government took a shareholding in an existing bank. Mintoff, however, wanted Barclays to terminate its employment contracts first and then re-employ its staff in the name of the new bank, as a result of which Barclays would have to make a terminal benefit payment (BHOM, 1975; BGA, 1975f). In this way, those members of staff whose salaries were reduced 
would receive compensation from Barclays. This expectation, thus, was a reflection of Mintoff's regression to his state control policy. In order to promote this requirement, the terms as to how Barclays' staff should be transferred to the Mid-Med Bank were missing from the Agreement.

Second, although Mintoff promised to Barclays that the government would not in any way interfere with Barclays' management of the new bank, the dominant state control policy would induce him to prepare for the potential risk of Barclays' subsequent management neither complying with general government policy nor acting in the best interests of the new bank. In order to guard against this risk, it was stipulated in the Agreement that the government would nominate the majority of the Mid-Med Bank Board members, i.e. the Board was to be controlled by the government. Although the General Manager was nominated by Barclays, there were no terms indicating his duties and authority (BGA, 1975g).

Third, although Mintoff wanted the partnership to last, the state control policy also induced him to prepare for the potential risk that Barclays’ performance in attracting foreign capital to Malta would prove unsatisfactory, i.e. his perception of Barclays’ role was disproved. In order to guard against this risk, an optional term was added to the Agreement, which entitled the government to purchase Barclays’ 40 per cent shares at their net asset value (BGA, 1975g). This optional term thus also foreshadowed the obsolescence of Barclays’ bargaining power and the bargain itself. 
In spite of Barclays' engagement policy, its decision makers’ reliability was also bounded due to the bank's vulnerable position in the partnership. This vulnerability made them have no choice but commitment failure or withdrawal to guard against the potential risk of the Maltese government's later behaviour not being beneficial to Barclays' objectives. In order to facilitate withdrawal, an optional term was added to the Agreement, which entitled Barclays to sell its shares to the government (BGA, 1975g). Barclays also prepared for the obsolescence of the bargain.

Due to the aforementioned context, the British government adopted a non-involvement attitude towards the partnership (Moreton, 1972; NA, 1975a, 1977a), which on the one hand, increased the vulnerability of Barclays and strengthened its decision makers' choice of commitment failure in the event of any subsequent unsatisfactory actions by the MLP government; on the other hand, it indulged Mintoff's bounded reliability. In addition, as the MLP government agreed that all Barclays’ Maltese employees would be offered employment in the Mid-Med Bank, there was no argument from the relevant trade union, the MUBE, about the terms of the Agreement.

The bounded reliability of the two partners' decision makers developed at the formative stage thus portended their post-formation commitment failure and the obsolescence of their bargain. In the following sections, we explore how decision-makers' bounded reliability developed to lead to their commitment failure and eventual partnership 
termination.

\section{Mintoff's Regression to State Control Policy and Barclays' Terminal Benefit Payment}

After signing the Agreement and with no discussion with Barclays, Mintoff, induced by the dominant state control policy, decided to reduce some staff salaries in order to equate them with those in the Central Bank of Malta (BGA, 1975h). According to Mintoff's policy of nationalising private entities, the MLP government wanted Barclays to accept the responsibility for compensating for these salary reductions through a terminal benefit payment. This was a reflection of Mintoff's commitment failure. The absence of terms about staff transfer in the Agreement thus gave the government an opportunity to demand the terminal benefit payment.

According to Barclays’ Rules of the Pension Fund (BGA, 1951), Barclays was allowed to reduce pensions by the actuarial value of sums already paid out in terminal benefits (Tuke, 1975). This, however, immediately provoked a threat of industrial action from the MUBE. Although Mintoff never acknowledged the importance the MUBE deserved as he regarded it as an over-privileged group, Mintoff supported it in obtaining the terminal benefit payment with no corresponding pension deduction. Correspondingly, he expressed his displeasure to Barclays, threatening to reconsider its position in the partnership, if the latter would not satisfy the MUBE (Tuke, 1975; BGA, 1975f). The 
unanticipated MUBE threat of industrial action thus indirectly supported Mintoff's commitment failure by putting extra pressure on Barclays to make the payment.

Facing the threat from Mintoff and the MUBE, Barclays' Board discussed possible solutions and their impact on Barclays. First, if Barclays paid the terminal benefits of M£1.044 million without reducing pensions by the actuarial value of the payment, in accordance with the Rules of the Pension Fund, there would be subsequent repercussions and precedents created in other parts of the world (Shaw, 1975b). Second, if Barclays decided to reduce pensions by the actuarial value of the payment, it would find itself launching the new bank while facing opposition from both the government and the staff, which would be less than ideal (BGA, 1975i). Third, their bounded reliability also drove them to consider the possibility of withdrawal, which was, however, opposed by their local managers who felt confident that there would be little government intervention in running the new bank, as had been the past experience of the Bank of Valletta. In addition, everyday relations were reasonable between Barclays and the Maltese government and it was usually possible to do business with Mintoff and his close advisers in an amiable and workmanlike fashion (BGA, 1975j). If Barclays withdrew at this stage and in such circumstances, it would be politically embarrassing to both the British and Maltese governments and the Bank might encounter difficulties in withdrawing its assets from Malta and then only on the most unfavourable terms (BGA, 1975f). 
After the above discussion, the Board members eventually agreed that the proposed partnership still had its merits in terms of achieving Barclays' objectives. Tuke concluded that it was better to retain a stake in the Maltese operation (Tuke, 1975). Following its engagement policy, Barclays’ Board thus decided to show its commitment to the partnership by satisfying the government requirement to the extent that its estimated net profits in Malta in 1975 allowed. This included offering staff a favourable pension, providing ex-gratia payments to those staff members taking salary reductions and transferring half of its net profits for 1975 in Malta to reserves, as a gesture of goodwill to the government. Barclays’ commitment achieved the understanding and support of the government and thus helped maintain their partnership. The MUBE eventually accepted the situation (Tuke, 1975; BGA, 1975f).

Mintoff's Regression to State Control Policy for the Second Time and the MLP

\section{Government Intervention in Barclays’ Management}

Mintoff had a substantial success in the 1976 General Election and his success confirmed an increased level of support and personal loyalty in his party although some MLP members disliked his autocratic behaviour (NA, 1978d; Shaw, 1975b; Turner, 1977). There was a conviction in the majority of the people that he was the best man to tackle the problems that confronted Malta after 1979. Therefore, the people around him, i.e. his civil servants, behaved like ‘sycophants' and 'yes-men’ (Shaw, 1975b). Furthermore, given that a proportional representation system regulated that the final 
ballot results in the Parliament had to be proportional to the number of votes polled by each party contesting the election, the MLP's success in the General Election thus greatly strengthened Mintoff's dominant position in the government (Mizzi, 1995).

In order to achieve his objectives, Mintoff adopted a series of changes in government policy from 1976, which affected the interests of the relevant groups. As a result, 1977 was a turbulent year during which Malta experienced many strikes and social unrest, regarding specific government policies (Eldred, 1977). The NP encouraged the demonstrations and supported the unions’ disputes with the government (NA, 1977a).

Throughout the summer there was industrial action against the policy change towards the night-shift of Telemalta, the state communication company (NA, 1978a). Their union asked the MUBE to instruct its members to stop handling Telemalta accounts. The government, however, stated that all bank employees must sign a declaration confirming they would not discriminate against any account-holder. In the event of a refusal to sign the declaration, a staff member would be suspended without pay or benefits. Due to the MUBE’s instruction, 63 per cent of the Mid-Med Bank staff were suspended accordingly (BGA, 1977a).

During the industrial action, the government asked Barclays to provide two members of staff for the Mid-Med Bank to maintain its operations. Barclays, however, declined the request, as it did not want to interfere in accordance with its policy of non- 
intervention in industrial disputes (Blackburn, 1967). In spite of Barclays’ explanation, its unsupportive attitude materialised Mintoff's anticipated risk that Barclays’ postformation management might not be complying with government policy, which thus triggered his planned commitment failure by regressing to the state control policy (BGA, 1977a). As the terms of the role of the General Manager were lacking in the Agreement and the government controlled the Board, government intervention in Barclays' management was thus legitimised (Ball, 1978). The government started to intervene by placing its own supporters in key branches and sections, so that, in the event of further industrial disputes, the Bank would be able to continue to operate (BGA, 1977b). In addition, the government never permitted the Management Committee to function free from government interference (Galea, 1977), which eventually led the General Manager, Curmi, to tender his resignation (BGA, 1977c).

During this period, there occurred some other unanticipated incidents which damaged the relationship between the British and the Maltese governments, such as the support of the British Medical Association for the strike of Maltese doctors, the involvement of the British National Union of Seamen in the strikes organised by the CMTU and the critical report on Mintoff and his action by the British press (Mintoff, 1977; NA, 1977b). In retaliation, the Maltese government withdrew co-operation with the British Forces in matters that did not fall strictly within the terms of the Military Facilities Agreement, by forbidding social contact between its officials and the British High Commission and generally by encouraging a hostile climate of opinion towards Britain (Winchester, 
1977b). These unanticipated contingencies did not, however, change the British government's policy and its non-involvement attitude towards Barclays' partnership with the MLP government. First, the British government had little to offer Malta after 1979, which placed it in a somewhat unfavourable position regarding negotiations with the Maltese government (Purcell, 1977). Second, given that the subsequent years of the run-down of British forces were likely to give rise to many minor clashes of interest, in order to prevent the MLP government from causing substantial damage to British government interests, the latter's policy in relation to Malta remained consistent: keeping a good relationship with the Maltese government (NA, 1977a). In order to appease Mintoff, the British Prime Minister, James Callaghan, wrote to him to apologise for what had happened, underlining that, 'the British government has no intention of interfering in the internal affairs of Malta' and the British Treasury agreed that up to $£ 1.53$ million worth of surplus assets might be transferred to the Maltese (Callaghan, 1977). The British government policy and apology thus indirectly indulged the MLP government intervention in Barclays’ management.

Facing Mintoff's regression to the state control policy once again, Barclays Board members, however, decided to accept the government intervention as it did not seriously endanger the bank's achieving its objective. Barclays was still achieving returns of around 25-30 per cent after tax on its capital invested (BGA, 1977b). Board members thus decided to preserve the 40 per cent shareholding. They then convinced Curmi to withdraw his resignation. In order to appease the government, Barclays 
provided it with advice on how to minimise the risks and damage caused by the strikes (BGA, 1977a).

\section{Mintoff's Regression to State Control Policy for the Third Time and Partnership Termination}

The 1977 strikes had a profound impact on the trade unions, which was reflected by their later polarised objectives: the GWU supported the MLP while other unions, if not actually supporting the NP, opposed Mintoff and his policies (Mizzi, 1995). Facing the challenges of the CMTU and other Unions, the MLP government responded by proposing a merger with the GWU. Although there was some reluctance to this merger, it was quickly quashed by the removal of opponents from office, such as the SecretaryGeneral, Mr. Attard Kingswell and his loyal supporters (NA, 1978a). On May 211978 GWU delegates approved the statutory 'fusion’ with the MLP (Mizzi, 1995).

After the strikes, Mintoff's popularity and support from both his party and the public were lessened (NA, 1978a, 1980b). Mintoff's autocratic rule was, however, virtually unchallenged. First, the merger between GWU and MLP resulted in the GWU being totally subservient to Mintoff's control, which greatly supported his power (NA, 1980b). Second, Mintoff increasingly used intimidation and political patronage to stifle dissent (NA, 1979). As a result, Mintoff dominated the NP, whose leaders openly expressed their fear that outright confrontation with the government might provoke Mintoff to 
‘precipitate a premature slide into dictatorship' and Mintoff could be tempted to 'rule unconstitutionally by invoking a state of emergency’ (NA, 1979, 1980b).

Although Mintoff maintained his dominant control in government, a government study of the national economy in 1978 concluded that Malta was not strong enough to deal with the loss of foreign exchange earnings from the British military base. This result necessitated significant restructuring to be completed within the shortest possible time (NA, 1978b). If it proved impossible to find viable solutions to deal with the economic problems, Mintoff's popularity would be further weakened (NA, 1978c).

Mintoff had expected foreign companies to help attract foreign investment to Malta. The 1978 study, however, called for a re-appraisal of their efforts (NA, 1978d). The government reappraisal concluded that Barclays' performance in this respect was unsatisfactory, which thus materialised Mintoff's anticipated risk at the formative stage and countered his original belief of Barclays' bargaining power. The pressure on Mintoff to tackle the domestic economic problems motivated him to regress to the state control policy for the third time, i.e. to consider removing Barclays from the partnership. At this point, he decided to acquire 30 per cent of the Mid-Med Bank shares from Barclays (BGA, 1979a, 1979b). The optional terms added to the Agreement legitimised Mintoff's commitment failure by entitling the government to purchase Barclays' shares.

Simultaneously there was no possibility for the British government or the MUBE to 
influence the MLP government decision. The British government's experience in the 1977 strikes had strengthened its belief that the central policy in Malta should be to maintain a good relationship with the MLP government. Any issue that might cause damage to their relationship was dropped or dealt with by delaying tactics (NA, 1980a). As a result, it was unwilling to become involved in any bargaining with the MLP government. In addition, after the 1977 strikes, the key positions at the Mid-Med Bank were filled by people loyal to the MLP. The re-staffing and government intervention had significantly weakened the power of the MUBE in the Bank (Mizzi, 1995). In spite of its objective against the control of the MLP, the MUBE had to protect itself from further damage by acting with circumspection (NA, 1979, 1980b). As a result, it was unwilling to get involved in further bargaining with the MLP government.

Once Barclays' shareholding was reduced to 10 per cent, it was impossible to achieve its objective. Given the obsolescence of its bargaining power, although it re-negotiated with government officials, Mintoff did not want the Bank to retain a higher shareholding (BGA, 1979a, 1979b, 1979c), which thus triggered its planned commitment failure, i.e. withdrawal from the IJV partnership (Harrison, 1979a). The optional term in the Agreement that entitled Barclays to sell its shares to the government legitimised its withdrawal. The original bargain therefore obsolesced. Eventually, Mintoff agreed to buy Barclays' 40 per cent shareholding at the net asset value on $31^{\text {st }}$ December 1978, M£5.394 million — a reasonable price in Barclays’ opinion, which had not been possible three years earlier when Mintoff had wanted Barclays to remain 
a partner in the Mid-Med Bank (Harrison, 1979b).

\section{Conclusion}

This research contributes to the extant research on IJV termination by exploring its endogenous reasons from insights provided by the Mid-Med Bank during the period 1975-1979. It argues that the unanticipated termination of the Bank had endogeneity due to the bounded reliability of its partners' decision makers, developed from the formative stage by preparing for their commitment failure in the Agreement. Mintoff's bounded reliability in fulfilling his identity-based discordant promise to Barclays led to his regression to the state control policy with which he identified on three occasions, which eventually triggered Barclays’ planned commitment failure, i.e. withdrawal from the partnership.

Based on the IJV partnership, this research contributes to the extant bounded reliability theory from the following perspectives. First, it shows that partners' unequal positions tend to cause their decision makers to develop bounded reliability. For example, Barclays’ vulnerability contributed to its decision makers' bounded reliability as they had no other choice but commitment failure when an unfavourable situation occurred. The MLP government's dominant position indulged Mintoff's development of his bounded reliability due to the lack of opposition from other relevant organisations to this partnership. Second, the situation of a single person dominating a partner's internal 
decision-making process tends to indulge his or her development of bounded reliability due to the lack of checks and balances. For example, the dominant position of Mintoff in the MLP government contributed to his development of bounded reliability due to the lack of internal opposition. Third, decision makers' commitment failure must be legitimised, i.e. they must have developed bounded reliability at the formative stage by preparing for commitment failure in the Agreement.

Furthermore, this research also contributes to the extant OBT from the following perspectives. First, the existence of bargaining power can rely on bargainers’ belief. Even though an MNC's investment was sunk and the host government acquired the management capability, the government could still assume that the MNC possessed relative bargaining power based on the former's perception of the latter's role in helping achieve its goal. Second, the obsolescence of a bargain has endogeneity due to the bounded reliability of bargainers. Third, the obsolescence of a bargain must be legitimised, so the deterioration of the bargaining relationship starts not after the bargain was struck but from the outset.

In addition, the existing research concerning the contractual governance adopted by IJVs has mainly focused on its positive role in guarding against opportunism and dealing with possible contingencies after formation (Boyce and Lepper, 2002; Cheung, 1983; Luo, 2005; Macneil, 1974; Williamson, 1979). This research, however, shows that commitment failure also represents a choice in addressing the above problems and 
that contractual governance can play a role in preparing for that failure, which seems to have been ignored in the extant research about IJV termination.

The findings of this research thus indicate ways in which the contractual governance of IJVs might be improved. First, as context contributes to the bounded reliability of partners' decision makers at the outset of a contract, it is necessary for partners to conduct a thorough contextual analysis when planning to set up an IJV. If both partners are not on an equal footing, they should deliberate further, before signing the contract. Second, due to the crucial role played by agreements or contracts in preparing for commitment failure, partners should guard against terms that might legitimise their commitment failure. Third, the influence of Mintoff's dominant position on his bounded reliability suggests the importance of examining the reliability of partners' single decision-maker before forming an IJV. If this decision-maker's character is one of unpredictability, the other partner should ask for the former's credible commitment in order to mitigate his bounded reliability.

\section{Acknowledgements}

Many thanks for the continuous support received from Barclays Group Archives and Maria Sienkiewicz. A special thank you for continuous encouragement and constructive comments received from Prof. Robin Pearson on past versions of this paper. Also greatly appreciate the two anonymous reviewers' constructive feedback. Without their support and guidance, I would not have been able to present the current paper.

\section{Notes on Contributor}


Dr Qing $\mathbf{L u}$ is a lecturer at the Hull University Business School. Her current research interests are international banking, merger and acquisition, business - government relationship. Until now, from her research, she has published a monograph and papers in book chapter and journals such as Enterprise \& Society and Business History.

\section{References}

Abdelrehim, N., \& Toms, S. (2017). The obsolescing bargain model and oil: The AngloIranian Oil Company 1933-1951. Business History, 59(4), 554-571.

Ackrill, M., \& Hannah, L. (2001). Barclays: The business of banking 1690-1996. Cambridge: Cambridge University Press.

Alexander, D. C. (1975). Letter 17 July, National Archives (hereafter NA) FCO 9/2258.

Álvaro-Moya, A. (2015). Networking capability building in the multinational enterprise: ITT and the Spanish adventure (1924-1945). Business History, 57(7), 1082-1111.

Bai, C. E., Tao, Z., \& Wu, C. (2004). Revenue sharing and control rights in team production: Theories and evidence from joint ventures. RAND Journal of Economics, 35(2), 277-305.

Baldacchino, G. (2009). Trade Unions in Malta. Brussels: ETUI.

Ball, K. J. (1978). Letter to A. R. Curmi 30 August, Barclays Group Archives (hereafter BGA) ACC 80/4452.

Barclays Group Archives. (1951). 'ACC 38/954: Pension Fund Rules, 1951'.

Barclays Group Archives. (1959). 'E42: DCO Quarterly, volume 5, pages 243, 252'.

Barclays Group Archives. (1963). 'E42: DCO Quarterly, volume 6, page 586’.

Barclays Group Archives. (1965). 'E42: DCO Quarterly, volume 7, page 147’.

Barclays Group Archives. (1971). 'ACC 80/5975: Objectives of Barclays Bank International, November 29'.

Barclays Group Archives. (1973a). 'E47: BBI Report and Accounts 1973’.

Barclays Group Archives. (1973b). ‘ACC 80/5175: Visit to Malta - Mr. Mogford/Mr.

Moon - 13-15 December'.

Barclays Group Archives. (1974a). 'E72: Barclays International Directory, page 72'.

Barclays Group Archives. (1974b). 'E47: BBI Report and Accounts 1974’.

Barclays Group Archives. (1974c). 'ACC 80/4070: Extract from International

Newsletter, No. 1'.

Barclays Group Archives. (1974d). 'E206: Barclays International Quarterly, volume 3, page 189'.

Barclays Group Archives. (1975a). 'ACC 11/1422: Paper for Money Book,

September 5'.

Barclays Group Archives. (1975b). 'E47: BBI Report and Accounts 1975'.

Barclays Group Archives. (1975c). ‘BBI in New Malta Bank Link-up’, Barclays

Bulletin, Summer, page 2'. 
Barclays Group Archives. (1975d). 'E207: Barclays International Quarterly, volume 4, page 279'.

Barclays Group Archives. (1975e). 'ACC 80/5960: Staff Circular No. 6, March 25’. Barclays Group Archives. (1975f). ‘ACC 80/5960: Paper for Board Meeting, August 28'.

Barclays Group Archives. (1975g). 'ACC 80/5960: Heads of Agreement between the Government of Malta and Barclays International Limited, March 31'.

Barclays Group Archives. (1975h). 'ACC 11/1422: Note for the Chairman, July 1'.

Barclays Group Archives. (1975i). 'ACC 80/4070: Malta, August 18’.

Barclays Group Archives. (1975j). 'ACC 80/4070: Malta - Terminal Payments and Pension Liabilities, 13 August'.

Barclays Group Archives. (1977a). 'ACC 80/4452: Note for G. Thomson, Malta Visit - August 5/6'.

Barclays Group Archives. (1977b). ‘ACC 80/4453: Note to Mr. K. J. Ball October 3’. Barclays Group Archives. (1977c). ‘ACC 80/4452: Notes for Discussion with G.

Thomson, September 8'.

Barclays Group Archives. (1978a). ‘ACC 38/519: BBI Board Minutes, 11 May’. Barclays Group Archives. (1978b). ‘ACC 38/519: BBI Board Minutes, 25 May’. Barclays Group Archives. (1979a). 'ACC 11/1420: Telephone Conversation Ball/Duncan, January 9'.

Barclays Group Archives. (1979b). 'ACC 11/1420: Money Book, January 16’. Barclays Group Archives. (1979c). 'ACC 11/1420: Money Book, February 8’. Barclays Head Office in Malta. (1975). Letter to J. P. G. Wathen 31 January, BGA ACC 80/5960.

Beamish, P. W., \& Banks, J. C. (1987). Equity joint ventures and the theory of multinational enterprise. Journal of International Business Studies, 19(2), 1-16.

Berlew, E. K. (1984). The Joint Venture - a way into foreign markets. Harvard Business Review, July-August, 48-54.

Blackburn, R. M. (1967). Union character and social class. Sheffield: Batsford.

Boyce, G., \& Lepper, L. (2002). Assessing information quality theories: The USSCo. joint venture with William Holyman \& Sons and Huddart Parker Ltd, 1904-35. Business History, 44(4), 85-120.

Buckley, Peter J., \& Mark Casson. (1976). The future of the multinational enterprise. Basingstoke and London: Macmillan.

Callaghan, J. (1977). Letter to D. Mintoff 6 October, NA FCO 9/2582.

Cheung, S. N. S. (1983). The contractual nature of the firm. Journal of Law and Economics, 26, 1-21.

Coates, K. (1977). Democracy in the Labour Party. Nottingham: Spokesman.

Colli, A. (2014). Multinationals and economic development in Italy during the twentieth century. Business History Review, 88(2), 303-327.

Danermark, B., Ekström, M., Jakobsen, L., \& Karlsson, J. Ch. (1997). Explaining society: Critical realism in the social sciences. London: Routledge.

Dunning, J., \& Lundan, S. M. (2008). Multinational enterprises and the global economy ( $2^{\text {nd }}$ ed.). Cheltenham: Edward Elgar. 
Eldred, J. S. (1976). Letter to S. E. Turner, 29 December, NA FCO 9/2407.

Eldred, J. S. (1977). Letter to S. E. Turner 21 March, NA FCO 9/2580.

Foley, M. (2000). The British Presidency. Manchester: Manchester University Press. Foss, N. J., \& Weber, L. (2016). Moving opportunism to the back seat: Bounded rationality, costly conflict, and hierarchical forms. Academy of Management Review, 41(1), 61-79.

Galea, L. E. (1977). Letter to G. A. O. Thomson 17 August, BG ACC 11/1364'.

Gould, J. A., \& Winters, M. S. (2007). An obsolescing bargain in Chad: Shifts in leverage between the government and the World Bank. Business and Politics, 9(2), Art. 4, 1-34.

Haggard, S. (1989). The political economy of foreign direct investment in Latin America. Latin American Research Review, 24(1), 184-208.

Harrison, A. M. (1979a). Letter to the Chief Inspector. 15 March, BGA ACC 11/1420.

Harrison, A. M. (1979b). Letter to L. E. Galea. 28 February, BGA ACC 11/1420.

Haydon, W. R. (1975). Letter to S. J. Barrett. 5 February, NA FCO 9/2258.

Hennart, J. (1988). A transaction costs theory of equity joint ventures. Strategic Management Journal, 9, 141-158.

Inkpen, A. C., \& Beamish, P. W. (1997). Knowledge, bargaining power, and the instability of international joint ventures. Academy of Management Review, 22(1), 177202.

Inkpen, A. C. (2009). Strategic alliances. In A. M. Rugman (Ed.), The Oxford handbook of international business (2nd ed., pp. 389-414). Oxford: Oxford University Press.

Jones, G. (2004). Multinationals and Global Capitalism from the Nineteenth to the Twenty-first Century. Oxford: Oxford University Press.

Jones, S. R. H. (2003). Brand building and structural change in the Scotch whisky industry since 1975. Business History, 45(3), 72-89.

Kano, L., \& Verbeke, A. (2015). The three faces of bounded reliability: Alfred Chandler and the micro-foundations of management theory. California Management Review, 58(1), 97-122.

Kennedy, C.R. (1992). Relations between transnational corporations and governments in host countries: A look to the future. Transnational Corporations, 1(1): 67-91.

Killing, J. P. (1982). How to make a global joint venture work. Harvard Business Review, 60(3), 120-7.

Kobrin, S.J. (1984). Expropriation as an attempt to control foreign firms in LDCs: Trends from 1960 to 1979. International Studies Quarterly, 28(3): 329-48.

Langley, A. (2009). Studying processes in and around organizations. In D. Buchanan, \& A. Bryman (Ed.), Sage Handbook of Organizational Research Methods (pp. 409429). London: Sage Publications.

Lee, K., \& Jin, X. (2009). The origins of business groups in China: An empirical testing of the three paths and the three theories. Business History, 51(1), 77-99.

Lumineau, F., \& Verbeke, A. (2016). Let's give opportunism the proper back seat. Academy of Management Review, 41(4), 739-754.

Luo, Y. (2005). Transactional characteristics, institutional environment and joint venture contracts. Journal of International Business Studies, 36, 209-230. 
Macneil, I. R. (1974). The many features of contract. Southern California Law Review, 47, 691-816.

Makino, S., Chan, C. M., Isobe, T., \& Beamish, P. W. (2007). Intended and unintended termination of international joint ventures. Strategic Management Journal, 28, 11131132.

Malta Chamber of Commerce. (1974). Development Plan for Malta 1973-1980. Malta: Office of the Prime Minister.

Marcos, J., \& Prior, D. D. (2017). Buyer-supplier relationship decline: A norms-based perspective. Journal of Business Research, 76, 14-23.

McGovern, T., \& McLean, T. (2017). The genesis of the electricity supply industry in Britain: A case study of NESCo from 1889 to 1914. Business History, 59(5), 667-689.

Menard, S. (2008). Handbook of longitudinal research: Design, measurement and analysis. London: Academic Press.

Michie, R. C. (1978). The transfer of shares in Scotland, 1700-1820. Business History, 20(2), 153-164.

Mintoff, D. (1977). Letter to J. Callaghan 6 October, NA FCO 9/2582.

Mizzi, E. (1995). Malta in the making, 1962-1987. Malta: Beck Graphics Limited.

Moreton, J. O. (1972). Letter to Sir A. Douglas 13 July, NA T317/1661.

National Archives. (1967). 'CAB 148/30, OPD 7(67)2: Malta: consequences of a total withdrawal of British forces, February 10'.

National Archives. (1975a). 'FCO 9/2258: Malta: Post-1979, May 26’.

National Archives. (1975b). 'FCO 9/2254: Background Notes on Malta, December

11 '.

National Archives. (1975c). 'FCO 9/2258: Malta, March 4'.

National Archives. (1975d). 'FCO 9/2254: Mintoff- The Concentration of Power, 7

May 1975'.

National Archives. (1975e). 'FCO 9/2254: Malta: Labour Affairs'.

National Archives. (1975f). 'FCO 9/2258: Malta Development Plan (1973-1980), July 2'.

National Archives. (1976a). 'FCO 9/2408: Background Note, July 28'.

National Archives. (1976b). 'FCO 9/2406: Malta: Annual Review for 1975, 1

January'.

National Archives. (1977a). 'FCO 9/2580: First Impressions of Malta, 21 March'.

National Archives. (1977b). 'FCO 9/2582: Anglo-Maltese Relations, September 15’.

National Archives. (1978a). 'FCO 9/2747: Malta: Annual Review for 1977, January 4'.

National Archives. (1978b). 'FCO 9/2746: Background Note, December 1'.

National Archives. (1978c). 'FCO 9/2746: British Policy in Malta, June 13'.

National Archives. (1978d). 'FCO 9/2747: Malta: Internal Situation, March 30’.

National Archives. (1979). 'FCO 9/2846: Malta: Annual Review for 1978, January 19'.

National Archives. (1980a). 'FCO 9/2990: British Policy towards Malta, January 31'. National Archives. (1980b). 'FCO 9/2988: Malta: Annual Review for 1979, January 9'. 
Oxley, J. E. (1997). Appropriability hazards and governance in strategic alliances: a transaction cost approach. Journal of Law, Economics and Organization, 13(2), 387409.

Parkhe, A. (1991). Interfirm diversity, organisational learning and longevity in global strategic alliances. Journal of International Business Studies, 22, 579-601.

Parkhe, A. (1993). 'Messy' research, methodological predispositions, and theory development in international joint ventures. Academy of Management Review, 18(2), 227-268.

Parliamentary Archives. (1975). 'HL/PO/PU/1/1975/C26: Ministers of the Crown Act 1975’.

Pilkington, A. (1996). Learning from joint venture: The Rover-Honda relationship. Business History, 38(1), 90-114.

Pugach, N. H. (1982). Keeping an idea alive: The establishment of a Sino-American bank, 1910-1920. Business History, 56(2), 265-293.

Purcell, R. M. (1977). Anglo-Maltese Relations - UK Policy Towards Malta, November 29.

Richardson, P. (1984). Nobels and the Australian mining industry, 1907-25. Business History, 26(2), 156-192.

Rizzo, S. (2009). Towards a more Europeanised industrial and employment relations. In P. G. Xuereb (ed.) Malta and the European Union: Five Years On (pp. 19-28). Malta: University of Malta.

Rugman, A., \& Verbeke, A. (2005). Towards a theory of regional multinationals: A transaction cost economics approach. Management International Review, 45(1), 5-17. Rugman, A. M. (1979). International diversification and the multinational enterprise. Lexington, MA: D.C. Heath.

Shaw, M. H. (1975a). Letter to R. H. Baker 7 May, NA FCO 9/2254.

Shaw, M. H. (1975b). Letter to R. H. Baker 28 October, NA FCO 9/2254.

Shaw, M. H. (1975c). Letter to R. H. Baker 19 August, NA FCO 9/2254.

Tignor, R.L. (1998). Capitalism and Nationalism at the End of Empire. Princeton: Princeton University Press.

Tuke, A. (1975). Letter to L. Spiteri 28 August, BGA ACC 80/5960.

Turner, S. E. (1977). Is Mr. Mintoff Becoming More Conciliatory, 6 January, NA FCO 9/2580.

Undy, R., \& Martin, R. (1984). Ballots and Trade Union Democracy. Oxford: Basil Blackwell.

Verbeke, A., \& Greidanus, N. (2009). The end of the opportunism vs. trust debate: Bounded reliability as a new envelope concept in research on MNE governance. Journal of International Business Studies, 40, 1471-1495.

Verbeke, A., \& Kano, L. (2010). Transaction cost economics (TCE) and the family firm. Entrepreneurship Theory and Practice, 34(6), 1173-1182.

Verbeke, A., \& Kano, L. (2012). The transaction cost economics theory of the family firm: Family-based human asset specificity and the bifurcation bias. Entrepreneurship Theory and Practice, 36(6), 1183-1205.

Verbeke, A., \& Kano, L. (2013). The transaction cost economics (TCE) theory of 
trading favors. Asia Pacific Journal of Management, 30(2), 409-431.

Vernon, R. (1971). Sovereignty at bay. London: Basic Books.

Wathne, K. H., \& Heide, J. B. (2000). Opportunism in interfirm relationships: Forms, outcomes, and solutions. Journal of Marketing, 64 (October), 36-51.

Wilkins, M. (1970). The emergence of multinational enterprise: American business abroad from the colonial era to 1914. Cambridge, Mass.: Harvard University Press.

Wilkins, M. (2009). The history of the multinational enterprise. In A. M. Rugman (Ed.) The Oxford Handbook of International Business (2nd ed., pp. 3-38). Oxford: Oxford University Press.

Williamson, O. E. (1975). Markets and hierarchies: Analysis and antitrust implications. New York: The Free Press.

Williamson, O. E. (1979). Transaction-cost economics: The governance of contractual relations. The Journal of Law and Economics, 22, 233-261.

Williamson, O. E. (1985). The economic institutions of capitalism. New York: The Free Press.

Winchester, I. S. (1977a). Anglo-Maltese Relations Post-1979, 4 November, NA FCO 9/2579.

Winchester, I. S. (1977b). Anglo-Maltese Relations, 10 October, NA FCO 9/2582. 